\title{
Prefrontal $\mathrm{GABA}_{\mathrm{B}}$ Receptor Activation Attenuates Phencyclidine-Induced Impairments of Prepulse Inhibition: Involvement of Nitric Oxide
}

\author{
Kim Fejgin ',3, Erik Pålsson 1,2,3, Caroline Wass', Niall Finnerty ${ }^{2}$, John Lowry ${ }^{2}$ and Daniel Klamer*,1 \\ 'Department of Pharmacology, Institute of Neuroscience and Physiology, The Sahlgrenska Academy at University of Gothenburg, Gothenburg, \\ Sweden; ${ }^{2}$ Department of Chemistry, National University of Ireland Maynooth, Maynooth, Ireland
}

\begin{abstract}
Recent theories propose that both GABA and glutamate signaling are compromised in patients with schizophrenia. These deficits can be observed in several brain regions including the prefrontal cortex (PFC), an area extensively linked to the cognitive dysfunction in this disease and notably affected by NMDA receptor antagonists such as phencyclidine (PCP). We have previously demonstrated that inhibition of the nitric oxide (NO) pathways in the brain, particularly in the PFC, prevents a wide range of PCP-induced behavioral deficits including disruption of prepulse inhibition (PPI). This study investigated the role of $G A B A_{B}$ receptor signaling and $\mathrm{NO}$ in the effects of PCP on PPI. Mice received systemic or prefrontal injections of the GABA $\mathrm{B}_{B}$ receptor agonist baclofen $(2.5-5 \mathrm{mg} / \mathrm{kg}$ and I mM) before PCP treatment $(5 \mathrm{mg} / \mathrm{kg})$ and were thereafter tested for PPI. GABA/NO interactions were studied by combining baclofen and the $\mathrm{NO}$ synthase inhibitor L-NAME $(20 \mathrm{mg} / \mathrm{kg})$ in subthreshold doses. The role of GABA $\mathrm{B}_{\mathrm{B}}$ receptors for $\mathrm{NO}$ production in vivo was assessed using NO-sensors implanted into the rat PFC. PCP-induced PPI deficits were attenuated in an additive manner by systemic baclofen treatment, whereas prefrontal microinjections of baclofen completely blocked the effects of PCP, without affecting PPI per se. The combination of baclofen and L-NAME was more effective in preventing the effects of PCP than any compound by itself. Additionally, baclofen decreased $\mathrm{NO}$ release in the PFC in a dose-related manner. This study proposes a role for GABA $\mathrm{B}_{\mathrm{B}}$ receptor signaling in the effects of PCP, with altered NO levels as a downstream consequence. Thus, prefrontal NO signaling mirrors an altered level of cortical inhibition that may be of importance for information processing deficits in schizophrenia.
\end{abstract}

Neuropsychopharmacology (2009) 34, 1673-1684; doi:10.1038/npp.2008.225; published online I4 January 2009

Keywords: prefrontal cortex; schizophrenia; phencyclidine; prepulse inhibition; baclofen; GABA-B

\section{INTRODUCTION}

Inhibitory neurotransmission appears to be impaired in patients with schizophrenia as evidenced by the large number of clinical studies implicating deficits in the GABA system. These deficits range from reduced amounts of mRNA coding both for the main GABA-generating enzyme, glutamic acid decarboxylase $\left(\mathrm{GAD}_{67}\right)$ and the GABA membrane transporter GAT-1 (for review see Hashimoto et al, 2008), to lowered levels of GABA (Cross et al, 1979; Perry et al, 1979) and a modestly decreased density of GABAergic interneurons (Benes et al, 1991, 2001). In addition, signs of such a hypofunction have been observed

\footnotetext{
*Correspondence: Dr D Klamer, Department of Pharmacology, The Institute of Neuroscience and Physiology, Sahlgrenska Academy at the University of Gothenburg, Medicinaregatan I3, POB 43I, SE 40530 Gothenburg, Sweden, Tel: + 4631786 3403; Fax; + 4631786 3284, E-mail: daniel.klamer@pharm.gu.se

${ }^{3}$ These authors contributed equally to this work

Received II September 2008; revised 25 November 2008; accepted 2 December 2008
}

in many brain regions including areas that are considered central to the pathophysiology of schizophrenia such as the hippocampus (Benes, 1999), the anterior cingulate cortex (Woo et al, 2004) and the prefrontal cortex (PFC) (Akbarian et al, 1995; Hashimoto et al, 2003).

In parallel, excitatory glutamate receptors have been implicated in the pathophysiology of schizophrenia. This is based both on post-mortem studies showing changes in binding, transcription, and subunit expression of these receptors, and on altered levels of glutamate-related amino acids such as $\mathrm{N}$-acetylaspartate and $\mathrm{N}$-acetylaspartylglutamate (for review see Lewis and Moghaddam, 2006). In addition, noncompetitive NMDA receptor antagonists such as phencyclidine (PCP) induce behavioral changes in humans that resemble positive symptoms, negative symptoms, and cognitive deficits in schizophrenia (Freedman et al, 1987; Javitt and Zukin, 1991; Luby et al, 1959; Yesavage and Freman, 1978). The strategy of modeling aspects of schizophrenia in laboratory animals, by administration of noncompetitive NMDA antagonists such as PCP, MK-801, or ketamine has proven effective in mimicking 
certain features of schizophrenia including disrupted working memory (Jentsch et al, 1997; Wass et al, 2006b) and impaired preattentive information processing as measured by prepulse inhibition of the acoustic startle (PPI; Fejgin et al, 2007; Klamer et al, 2001; Linn et al, 2003; Mansbach and Geyer, 1989). In the light of this, NMDA receptor hypofunction has been suggested as a potential mechanism underlying certain aspects of schizophrenia.

Interestingly, both clinical and animal studies show that administration of NMDA antagonists produces signs of an increase, rather than an expected decrease, in cortical activity (Breier et al, 1997; Gozzi et al, 2008; Jackson et al, 2004; Lahti et al, 1995; Moghaddam et al, 1997). These findings have led to the proposition that NMDA receptors situated on GABAergic interneurons may be affected by this class of psychotomimetic substances (Homayoun and Moghaddam, 2007). NMDA channels are known to be especially important for interneuron activity (Grunze et al, 1996; Jones and Buhl, 1993) and a recent study of PFC function shows that inhibition of NMDA receptors preferentially decreases the activity of fast-spiking interneurons, thereby causing a disinhibition of pyramidal cells (Homayoun and Moghaddam, 2007). In line with this, a recent publication by Behrens et al showed that the noncompetitive NMDA receptor antagonist, ketamine, induces a dysfunction of cortical interneurons that can be rescued by a $\mathrm{GABA}_{\mathrm{A}}$ agonist (Behrens et al, 2007) and several studies have demonstrated deleterious effects of NMDA receptor antagonists on interneuron integrity and function. Taken together, this points to a possible interaction where glutamatergic output is disinhibited and subsequently increased as a consequence of a disrupted GABA system (for review see Lisman et al, 2008).

We have previously shown that the signaling molecule nitric oxide (NO) is important for the ability of PCP to induce schizophrenia-like behavior in rodents ranging from PPI to working memory (Klamer et al, 2004, 2005a; Palsson et al, 2007; Wass et al, 2006a, 2008). More specifically, an $\mathrm{NO} / \mathrm{cGMP}$ signaling mechanism in the medial PFC appears to be important for these effects as CGMP, the main effector of NO signaling, is increased in this region following PCP treatment and normalized by pretreatment with a NO synthase (NOS) inhibitor. Furthermore, prefrontal microinjections with an inhibitor of cGMP synthesis blocked the effects of PCP on PPI (Fejgin et al, 2008). These findings indicate that elevated levels of $\mathrm{NO}$ in the PFC may be important for the effects of PCP. A possible explanation for such an increase in NO production following NMDA receptor antagonist treatment, could be a higher prefrontal glutamate efflux caused by inhibition of interneuron output followed by a subsequent disinhibition of glutamate release. Tentatively, this increase in glutamate levels may activate non-NMDA glutamate receptors and thereby induce NO release. Notably, NO-producing cells in the rodent medial PFC, hippocampus, and the primate frontal cortex also synthesize GABA (Gabbott and Bacon, 1995; Szabadits et al, 2007; Yan et al, 1996), indicating a close relationship between NO and GABA signaling. The $\mathrm{GABA}_{\mathrm{B}}$ agonist baclofen has been shown to block the PPI deficits induced by the NMDA receptor antagonist MK-801 in both mice and rats, and also to improve spontaneous PPI deficits in DBA/ 2J mice (Arai et al, 2008; Bortolato et al, 2004, 2007). These findings demonstrate that $\mathrm{GABA}_{\mathrm{B}}$ signaling is important for the regulation of PPI and that the acute effects of NMDA antagonists may be mediated by disruption of interneuron function.

The aim of this study was to investigate the importance of $\mathrm{GABA}_{\mathrm{B}}$ and $\mathrm{NO}$ signaling, particularly in the PFC, for the disruptive effects of PCP on preattentive information processing. To this end, mice received both systemic and prefrontal injections of the $\mathrm{GABA}_{\mathrm{B}}$ receptor agonist baclofen before PCP treatment and were thereafter tested for PPI. To study GABA/NO interactions in relation to PPI, a combination of baclofen and the NOS inhibitor L-NAME were administered in doses not sufficient to block the effects of PCP per se. Finally, the regulatory role of $\mathrm{GABA}_{\mathrm{B}}$ receptors for $\mathrm{NO}$ production was assessed in vivo using novel, microelectrochemical NO-sensors implanted into the rat medial PFC.

\section{METHODS}

\section{Animals}

Male NMRI mice (Charles River, Germany or B\&K, Sweden; 25-35 g) and male Sprague-Dawley rats (Taconic, Denmark; 290-400 g) were used in this study. The animals were housed nine per cage (mice) or four (rats) per cage, in a colony room under constant temperature $\left(20 \pm 1^{\circ} \mathrm{C}\right)$ and humidity $(50 \pm 5 \%)$. Animals were allowed to acclimatize for at least 1 week before surgery or behavioral testing. The daylight cycle was maintained artificially (lights on from 0600 to 1800 hours) and behavioral experiments and biochemical measurements were conducted during the light phase. The Ethics Committee for Animal Experiments, Göteborg, Sweden, approved all experimental procedures used in this study.

\section{Drugs}

Phencyclidine hydrochloride (Sigma Chemicals, St Louis, MO, USA), R-baclofen (more active enantiomer; SigmaAldrich, Germany) and $N^{\mathrm{G}}$-nitro-L-arginine methyl ester (LNAME; Sigma-Aldrich) were used in this study. All drugs for systemic injections were dissolved in saline $(0.9 \% \mathrm{NaCl})$ and administered either intraperitoneally (i.p., mice) or subcutaneously (s.c., rats). Mice were always injected a volume of $10 \mathrm{ml} / \mathrm{kg}$ and rats $2 \mathrm{ml} / \mathrm{kg}$. For local injections, Rbaclofen was dissolved in Ringer's solution. The doses were chosen for optimal disruption of PPI (PCP $5 \mathrm{mg} / \mathrm{kg}$ ) and below the threshold for reversing these deficits (L-NAME) based on previously published studies (Klamer et al, 2001). Baclofen doses were based on PPI studies in mice (Arai et al, 2008; Bortolato et al, 2007) and rats (Bortolato et al, 2004).

\section{Surgical Procedure}

Local injection experiments. The mice were anesthetized with isoflurane (Isofluran Baxter; Apoteket AB, Sweden), placed in a Kopf stereotaxic instrument (David Kopf Instruments, Tujunga, CA, USA), and kept on a heating pad to prevent hypothermia and administered ketoprofen (Romefen, Veter, Sweden) to reduce postoperative pain. The 
skull was then exposed, and two holes for the guide cannulas (stainless steel, length $10 \mathrm{~mm}$, with an o.d./i.d. of $0.6 / 0.45 \mathrm{~mm}$ ), and one hole for an anchor screw were drilled. The coordinates used for the medial PFC region relative to the bregma were as follows: anterior $+1.8 \mathrm{~mm}$, lateral to midline $\pm 0.8 \mathrm{~mm}$, and ventral $1.0 \mathrm{~mm}$ from the brain surface (Franklin and Paxinos, 1996). The dura was removed using a sharp needle, and the guide cannulas and the anchor screw were secured with dental cement (Dentalon plus; AgnTho's AB, Lidingö, Sweden). After surgery the mice were administered $1 \mathrm{ml}$ of saline (s.c.) to prevent dehydration and allowed to recover for 3-4 days while housed individually in standard plastic cages.

NO measurements. The rats were anesthetized with isoflurane, placed in a Kopf stereotaxic instrument and kept on a heating pad to prevent hypothermia. An incision was placed down the midline of the skull and the bone was exposed. Four holes for the anchor screws, two holes for the reference (8T Ag wire, $200-\mu \mathrm{m}$ bare diameter; Advent Research Materials, UK) and auxiliary (8T $\mathrm{Ag}$ wire) electrodes, and one hole for the sensor electrode was drilled. Electrodes were then implanted following a previously described procedure (Lowry et al, 1997). The coordinates used for the medial PFC relative to bregma were as follows: anterior $+3.2 \mathrm{~mm}$, lateral to midline $\pm 0.8 \mathrm{~mm}$, and ventral $-4.2 \mathrm{~mm}$ from the brain surface. The electrode was inserted into the brain and connected to a pedestal that was secured to the anchor screws with dental cement. Sensor placement was balanced between the left and right hemispheres throughout the experiment. During surgery, the rats were administered $2.0 \mathrm{ml}$ of saline (s.c.), to reduce postoperative dehydration and an analgesic (carprofen) to reduce postoperative pain. The animals were allowed to recover for 2-4 days before commencing experiments. They were housed individually in standard plastic cages.

Probe and injection placement verification. After termination of the local injection and voltammetry experiments the mice and rats were decapitated. The brains were removed and frozen at $-80^{\circ} \mathrm{C}$. Injection or sensor placement was verified by sectioning the brains using a cryostat and an atlas of the mouse or rat brain for reference (Figure 1; Franklin and Paxinos, 1996; Paxinos and Watson, 2005).

\section{Prepulse Inhibition}

Apparatus. Acoustic startle was recorded using a MOPS 3 startle response recording system (Metod och Produkt Svenska AB, Sweden). The animals were placed in small plexiglass cages $\left(10 \times 5.5 \times 6 \mathrm{~cm}^{3}\right)$ that were suspended at the top to a piston. A movement of the animal in the cage caused a displacement of the piston, the acceleration of which was registered by a piezoelectric accelerometer. This signal was sampled and digitized by a microcomputer that also controlled the delivery of acoustic stimuli. Startle amplitude was defined as the maximum signal amplitude occurring 8-30 ms after the startle-eliciting stimulus. Four cages were used simultaneously and each cage was housed in a dimly lit and sound-attenuated cabinet $\left(52 \times 42 \times 38 \mathrm{~cm}^{3}\right)$. The cages were calibrated for equal sensitivity before testing and a mouse was always tested in

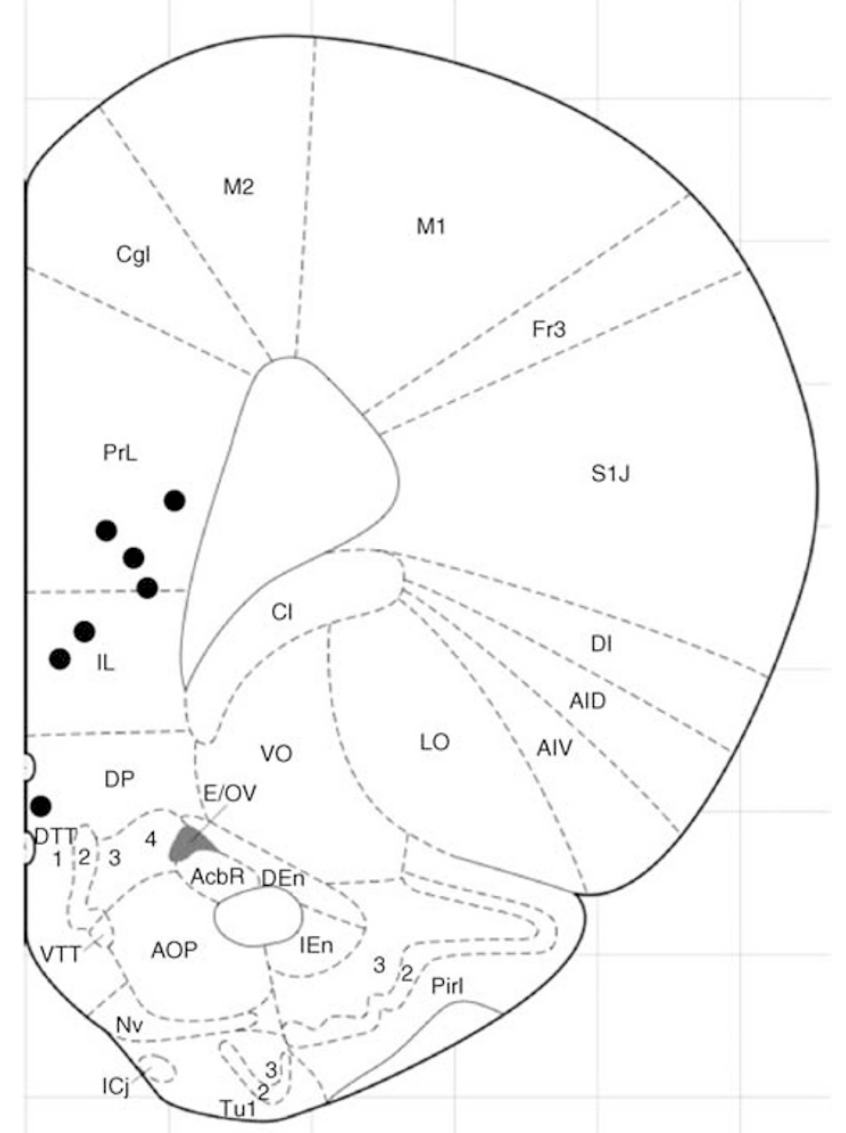

Figure I Coronal rat brain section of the medial PFC (AP $+3.24 \mathrm{~mm}$ from bregma) showing actual sensor placement. Each black circle represents the tip placement of one electrode $(n=7)$. Reprinted from The Rat Brain in Stereotaxic Coordinates (Paxinos and Watson, 2005) with permission from Elsevier.

the same cage at subsequent tests. The acoustic stimuli consisted of white noise, which was delivered by two highfrequency loudspeakers built into the ceiling of the cabinet.

PPI paradigm. Each test session started with an 8-min adaptation period containing only white background noise at $62 \mathrm{~dB}(\mathrm{~A})$. Startle pulse was set to $105 \mathrm{~dB}(\mathrm{~A})$ and prepulse intensities to 9,12 , and $15 \mathrm{~dB}(\mathrm{~A})$ above background. Duration of acoustic stimuli was set to $20 \mathrm{~ms}$ for both prepulses and startle pulses and interstimulus interval (ISI) was set to $40 \mathrm{~ms}$. The prepulse and pulse were discrete, and separated by the ISI. After the adaptation period, the animals were subjected to a series of five startle pulse-alone trials that were omitted from the analysis because they only served to accommodate the animals to the sudden stimulus onset. The animals were then subjected to a pseudorandomized combination of 3 prepulse-alone trials for each prepulse intensity, 45 pulse-alone trials, and 15 prepulse + pulse trials for each prepulse intensity. Trials were separated by $5-15 \mathrm{~s}$ intervals and all these intervals included a measurement of intertrial activity. This served as a general marker of basal animal activity (not stimulus evoked) throughout the experiment. The full PPI test lasted approximately $24 \mathrm{~min}$ including the adaptation period. 


\section{Electrochemical Detection of Nitric Oxide}

Prefrontal cortex NO levels were determined using a NO selective amperometric microsensor. The microsensor is a Nafion ${ }^{\circledR}$-modified Pt disk electrode (patent no. S2007/ 00774). The sensor design has been validated for in vitro and in vivo NO sensitivity (Brown et al, 2005; Finnerty, 2008 ) and in vitro selectivity against ascorbic acid, uric acid, and dopamine (Brown and Lowry, 2003). The NO oxidation current (electrode potential of $+0.90 \mathrm{~V}$ against an $\mathrm{Ag}$ reference electrode) was detected using a low-noise potentiostat (Biostat II; Electrochemical and Medical Systems, UK) and converted using an A/D converter (PowerLab; ADInstruments, United Kingdom). The digital signal was then recorded using Chart software (v5; ADInstruments) running on a PC. Each animal was connected to the in vivo voltammetry equipment on the day before an experiment to allow the NO oxidation current to reach a stable baseline. All experiments were carried out with the animal in its home cage. Rats were chosen for this experiment because the characterization of sensors has been carried out on this species and due to limitations regarding the size of the equipment.

\section{Experimental Layout}

All mice used for PPI testing were subjected to a pretest before surgery and/or drug treatment to ensure that they expressed basal startle reactivity.

Experiment 1: baclofen $2.5 \mathrm{mg} / \mathrm{kg}$. Each animal $(n=16)$ received all the four treatment combinations $(\mathrm{sal}+\mathrm{sal}$, baclofen + sal, sal + PCP, and baclofen + PCP) in a balanced crossover design. Each test was separated by a 3- to 4-day long washout period. Mice were first pretreated with baclofen at a dose of $2.5 \mathrm{mg} / \mathrm{kg}$ or saline and $53 \mathrm{~min}$, later they received the second injection consisting of PCP $(5 \mathrm{mg} /$ $\mathrm{kg}$ ) or saline. Seven minutes after the last injection the animals were placed in the startle cages for the adaptation period and subsequent PPI test.

Experiment 2: baclofen $5 \mathrm{mg} / \mathrm{kg}$. The mice $(n=16)$ were treated exactly as in the above experiment, but with a baclofen dose of $5 \mathrm{mg} / \mathrm{kg}$.

Experiment 3: local injection of baclofen into the medial prefrontal cortex. At the day of the experiment a dummy cannula was inserted and retracted from the cannula guides to reduce the risk of spreading depression. After this, the animals $(n=31)$ were allowed to rest for $60 \mathrm{~min}$ before a first PPI test. Based on the results of this test the animals were divided into four treatment groups with comparable basal PPI and startle reactivity: veh + sal $(n=8) ; \quad$ baclofen + sal $\quad(n=8) ; \quad$ veh + PCP $\quad(n=7)$, and baclofen + PCP $(n=9)$. The mice then received a bilateral injection of either $1 \mu \mathrm{l}$ baclofen or vehicle (Ringer's solution) $-1.6 \mathrm{~mm}$ below the brain surface. The local injection lasted $1 \mathrm{~min}$ and the cannula was left in place for another $45 \mathrm{~s}$ to allow diffusion of the drug. Immediately after the local injection the animals were administered PCP $(5 \mathrm{mg} / \mathrm{kg})$ or saline systemically and $7 \mathrm{~min}$ later they were placed in the startle chambers for the second PPI test.
Experiment 4: low dose of L-NAME. As above, the experiment used a balanced crossover design with a 3- to 4 -day long washout period. Each animal $(n=16)$ received all the four treatment combinations (sal + sal, L-NAME + sal, sal + PCP, and L-NAME + PCP). Pretreatment with a subthreshold dose of L-NAME $(20 \mathrm{mg} / \mathrm{kg}$ ) preceded the PCP injection $(5 \mathrm{mg} / \mathrm{kg})$ by $10 \mathrm{~min}$. Seven minutes later, the mice were placed in the startle cages.

Experiment 5: baclofen $2.5 \mathrm{mg} / \mathrm{kg}$ in combination with low dose of L-NAME. To examine the putative interactions between GABA and NO signaling in the brain mice $(n=16)$ were pretreated with a low dose of baclofen $(2.5 \mathrm{mg} / \mathrm{kg})$ in combination with a subthreshold dose of L-NAME $(20 \mathrm{mg} /$ $\mathrm{kg}$ ). Each mouse received all of the following four treatment combinations separated by a 3- to 4-day washout period: sal + sal + sal; baclofen + L-NAME + sal; sal + sal + PCP; and baclofen + L-NAME + PCP. These injections were identical in timing to the earlier systemic experiments using these compounds and thus also followed by a PCP injection $7 \mathrm{~min}$ before the beginning of the PPI test.

Experiment 6: NO measurements following dose response with baclofen. Each rat was subjected to four drug treatments with a 2-day washout period between each treatment. The drug treatments consisted of saline and baclofen at a dose of $2.5,5$, and $10 \mathrm{mg} / \mathrm{kg}$ (s.c.) and the doses were based on previous studies on baclofen and PPI in the rat (Bortolato et al, 2004). The order of the drug combinations was varied between animals in a balanced manner.

\section{Data and Statistical Analysis}

PPI. The mean response amplitude for pulse-alone trials $(\mathrm{P})$ was calculated for each mouse and test. This measure was used in the statistical analysis to assess drug-induced changes in acoustic startle response. The mean response amplitude for prepulse-pulse trials (PP) was also calculated and used to express the percent prepulse inhibition according to the following formula:

\section{Prepulse inhibition $(\%)=100-[(\mathrm{PP} / \mathrm{P}) \times 100]$}

Using this formula, a $0 \%$ value denotes no difference between pulse-alone and prepulse-pulse response amplitudes and consequently no PPI. Statistical analysis for systemic experiments was performed using a three-way repeated measures ANOVA with pretreatment (baclofen, LNAME, or sal), treatment (PCP or sal), and prepulse intensity $(9,12$, and $15 \mathrm{~dB})$ as within subject factors. Statistical analysis of the local injection experiments was conducted using a three-way mixed model ANOVA with pretreatment (baclofen or veh) and treatment (PCP or sal) as between-subject factors and prepulse intensity as withinsubject factor. There was a significant main effect of prepulse intensity in each PPI experiment (data not shown). As no prepulse intensity $\times$ pretreatment $\times$ treatment interaction effect could be demonstrated in any of the datasets, PPI data was collapsed across prepulse intensities and presented as an average \% PPI. Acoustic startle response (ASR) and intertrial activity (ITA) were analyzed using a two-way repeated measures or mixed model ANOVA with 
pretreatment and treatment as within- or between-subject factors depending on experiment type. Given the a priori hypothesis that baclofen and L-NAME would interfere with the effects of PPI, specific differences between treatment groups were evaluated in all experiments by Bonferroni's post hoc tests. Two-tailed levels of significance were used and $p<0.05$ was considered statistically significant.

NO measurements. The current over time (sampling rate 4/s) recorded in Chart was used as data. The mean of an approximately 5-min long sampling period just before drug treatment was used as baseline. The mean current change from baseline was calculated for a 5-min sampling period surrounding the time points of 30,60 , and 90 min after injection. This time frame was chosen to facilitate comparison with experiments 1-5 and previously published behavioral studies (Johansson et al, 1997; Klamer et al, 2005b; Wass et al, 2006a). To investigate whether the drug treatments had any significant effect on NO levels, a twoway repeated measures ANOVA with treatment and time point as within subject factors was used. In the presence of an interaction effect, his was followed by a one-way repeated measures ANOVA for each time point and where appropriate a Bonferroni's post hoc tests was performed for comparisons between groups. Two tailed levels of significance were used and $p<0.05$ was considered statistically significant.

\section{RESULTS}

Experiment 1: Baclofen $2.5 \mathrm{mg} / \mathrm{kg}$ does not Interfere with the Effects of PCP on PPI

Statistical analysis of PPI showed a significant effect of PCP $\left(5 \mathrm{mg} / \mathrm{kg}\right.$ ) treatment (effect of treatment, $\mathrm{F}_{(1,15)}=25.83$, $p<0.001)$ but not of pretreatment with baclofen $(2.5 \mathrm{mg} / \mathrm{kg})$. No pretreatment $\times$ treatment interaction effect could be demonstrated, suggesting that baclofen did not block the effects of PCP on PPI at this dose (Figure 2a). Post hoc comparisons showed that the baclofen + sal group did not differ from controls whereas PCP-treated animals showed a significantly lower PPI compared to the controls $(p<0.05)$. As already indicated by the lack of interaction, this effect was not prevented by pretreatment with baclofen because the PPI of the baclofen + PCP group was significantly lower than that of the control group $(p<0.05)$ but not different from the veh + PCP group.

There was no effect of drug treatment on ASR in experiment 1 (Table 1). Basal activity levels, as measured by ITA (Figure 3a), were significantly increased in PCPtreated animals (effect of treatment, $F_{(1,15)}=47.77$, $p<0.001$ ) and decreased in baclofen-treated animals (effect of pretreatment, $\left.\mathrm{F}_{(1,15)}=5.505, p<0.05\right)$. Pretreatment with baclofen partially blocked the PCP-induced hyperactivity as evidenced by a significant pretreatment $\times$ treatment interaction (interaction effect, $\mathrm{F}_{(1,15)}=5.985, p<0.05$ ). This was further supported by post hoc comparisons showing higher ITA in PCP-treated animals compared to controls $(p<0.001)$ whereas this could not be demonstrated for the baclofen + PCP group. However, the baclofen + PCP group did not show a significantly lower ITA than the PCP group, suggesting that the blockade was only partial.

\section{Experiment 2: Baclofen $5 \mathrm{mg} / \mathrm{kg}$ Elevates Basal PPI and Prevents the Effects of PCP}

PCP $(5 \mathrm{mg} / \mathrm{kg}$ ) had a main disruptive effect on PPI (effect of treatment, $\left.\mathrm{F}_{(1,15)}=74.02, p<0.001\right)$ whereas baclofen $(5 \mathrm{mg} / \mathrm{kg})$ increased PPI significantly (effect of pretreatment, $\mathrm{F}_{(1,15)}=45.01, p<0.001$; Figure $\left.2 \mathrm{~b}\right)$. Similar to the lower dose of baclofen, no pretreatment $\times$ treatment interaction effect could be observed, suggesting additive effects of baclofen and PCP. Post hoc comparisons revealed an increased PPI in the baclofen + sal group compared to
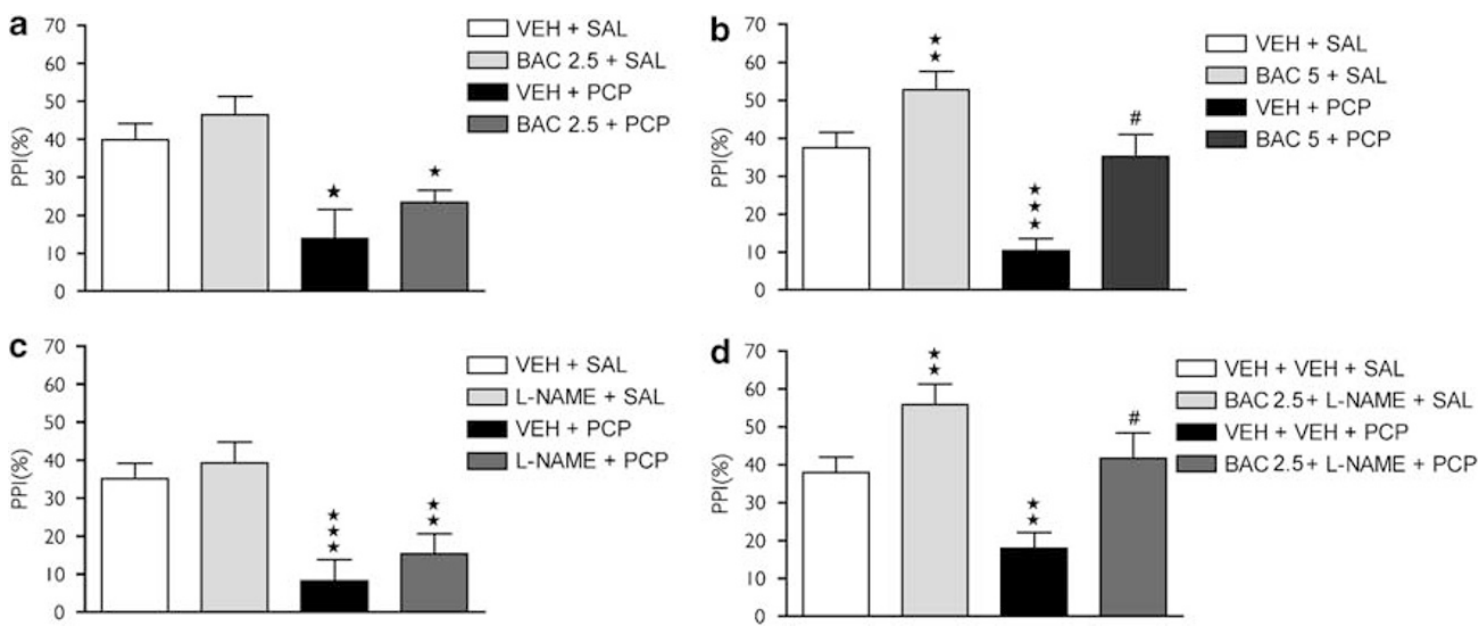

Figure 2 The effects of pretreatment with baclofen (BAC) and/or $N^{G}$-nitro-L-arginine methyl ester (L-NAME) on PCP-induced disruption of prepulse inhibition (PPI) in mice. Data are presented as mean PPI values collapsed over prepulse intensities \pm SEM for each treatment group. $\left({ }^{\star} p<0.05, \star \star p<0.0\right.$ I, $\star \star \star p<0.00$ I vs control group; ${ }^{*} p<0.05$ vs PCP group; Bonferroni's test). (a) A low dose of BAC (2.5 mg/kg) does not interfere with the effects of PCP $(5 \mathrm{mg} / \mathrm{kg})$ on PPI. (b) A high dose of BAC (5 mg/kg) attenuates the effects of PCP in an additive manner. (c) Pretreatment with a subthreshold dose of L-NAME $(20 \mathrm{mg} / \mathrm{kg})$ does not interfere with the effects of PCP on PPI. (d) Combination of BAC $(2.5 \mathrm{mg} / \mathrm{kg})$ and L-NAME $(20 \mathrm{mg} / \mathrm{kg})$ increases basal PPI and attenuates the effects of PCP on PPI in an additive manner. 
Table I Acoustic Startle Response (ASR) After Different Treatment Combinations in Experiments I-5

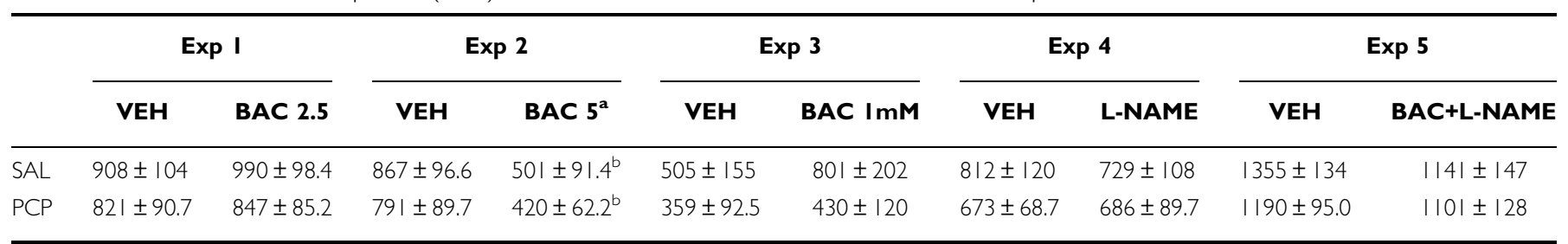

$a_{p}<0.05$ main effect of pretreatment following 3-way ANOVA.

$\mathrm{b}_{\mathrm{p}}<0.00 \mathrm{I}$ vs control group, Bonferroni's test.

Data are presented as mean ASR values \pm SEM for each treatment group. Baclofen (BAC; $2.5-5 \mathrm{mg} / \mathrm{kg}$ systemically or as bilateral microinjections I mM), $N^{G}$-nitro-Larginine methyl ester (L-NAME; $20 \mathrm{mg} / \mathrm{kg})$; and PCP $(5 \mathrm{mg} / \mathrm{kg}$ ) were administered in five separate experiments. The high dose of baclofen decreased ASR in experiment 2.
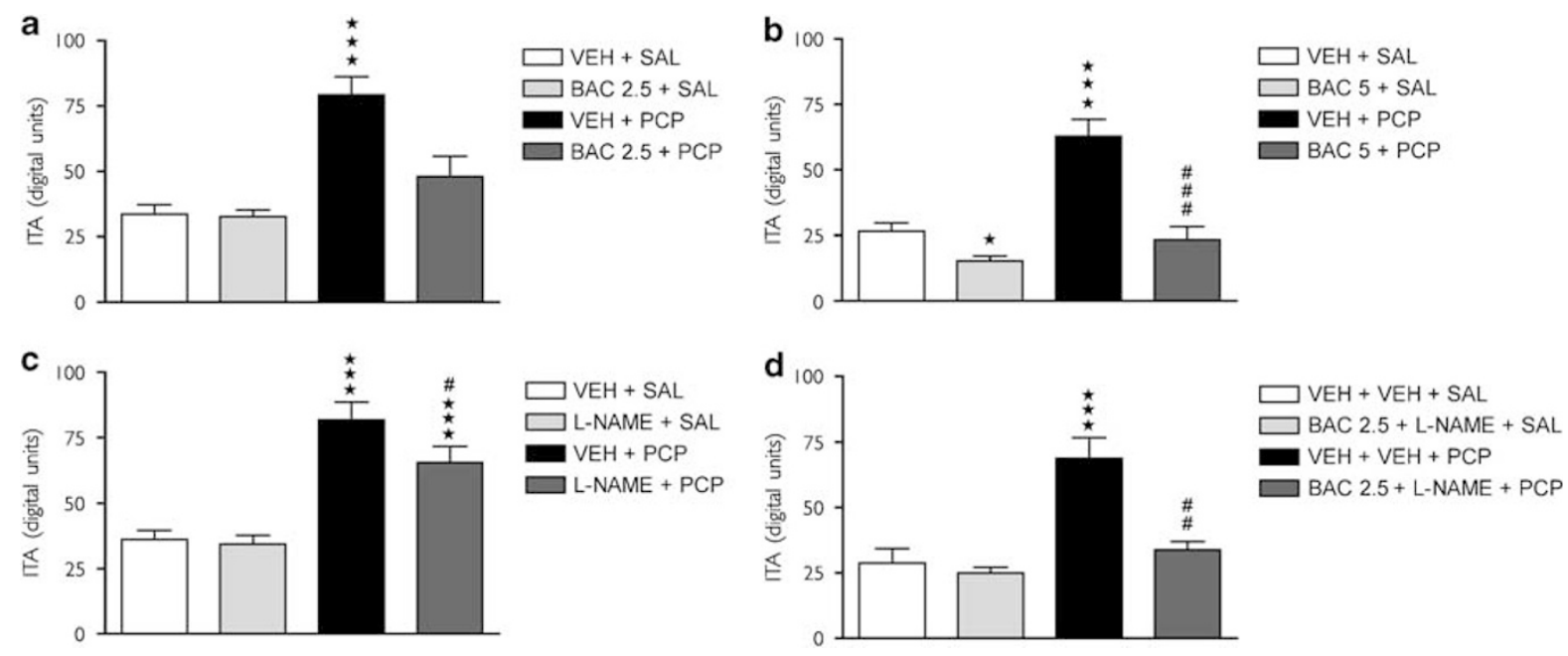

Figure 3 The effects of pretreatment with baclofen (BAC) and/or $N^{G}$-nitro-L-arginine methyl ester (L-NAME) on PCP-induced hyperactivity in mice as measured by intertrial activity (ITA). Data are presented as mean ITA values \pm SEM for each treatment group. ( ${ }^{\star} p<0.05,{ }^{\star} \star \star p<0.00$ I vs control group; ${ }^{\#} p<0.05,{ }^{\# \#} p<0.01,{ }^{\# \#} p<0.01$ vs PCP group; Bonferroni's test). (a) A low dose of BAC $(2.5 \mathrm{mg} / \mathrm{kg}$ ) partially interferes with the effects of PCP (5 mg/kg) on ITA. (b) A high dose of BAC (5 mg/kg) decreases ITA and blocks the PCP-induced hyperlocomotion. (c) Pretreatment with a subthreshold dose of L-NAME $(20 \mathrm{mg} / \mathrm{kg})$ partially attenuates the effects of PCP on ITA. (d) Combination of BAC $(2.5 \mathrm{mg} / \mathrm{kg})$ and L-NAME (20 mg/kg) blocks the PCP-induced hyperactivity.

controls $(p<0.01)$, suggesting an increasing effect of this dose of baclofen on PPI per se. PCP-treated animals had a lower PPI compared to controls $(p<0.001)$ and had also significantly lower PPI than the baclofen + PCP group $(p<0.01)$. Furthermore, baclofen + PCP-treated animals did not differ significantly from controls, indicating a normalization of PCP-induced PPI deficits by pretreatment with baclofen.

Statistical analysis of ASR (Table 1) showed that baclofen significantly lowered this measure (effect of pretreatment, $\left.\mathrm{F}_{(1,15)}=37.80, p<0.001\right)$ whereas no main effect of PCP treatment could be demonstrated. Post hoc comparisons showed that both the baclofen + sal group and the baclofen + PCP group had significantly lower ASR than controls $(p<0.001$ for both comparisons). Analysis of ITA showed a similar pattern to experiment 1 (Figure $3 \mathrm{~b}$ ). ITA was increased by PCP (effect of treatment, $\mathrm{F}_{(1,15)}=29.57$, $p<0.001$ ), decreased by baclofen (effect of pretreatment, $\left.\mathrm{F}_{(1,15)}=31.44, p<0.001\right)$, and a significant pretreatment $\times$ treatment interaction could be demonstrated (interaction effect, $\left.F_{(1,15)}=23.18, p<0.001\right)$. Post hoc comparisons showed a lower ITA in baclofen-treated mice compared to controls $(p<0.05)$. PCP-treated animals had a higher ITA than both controls $(p<0.001)$ and baclofen + PCP-treated animals $(p<0.001)$ suggesting a normalization of activity levels by baclofen. This was further supported by an absence of difference between the baclofen + PCP group and controls.

\section{Experiment 3: Prefrontal Injection of Baclofen Blocks PCP-Induced PPI Deficits}

Systemic PCP $(5 \mathrm{mg} / \mathrm{kg})$ injection disrupted PPI (effect of treatment, $\left.\mathrm{F}_{(1,28)}=8.744, p<0.01\right)$ whereas no main effect of local pretreatment with baclofen $(1 \mathrm{mM})$ could be shown (Figure 4a). A significant pretreatment $\times$ treatment interaction effect indicated that prefrontal pretreatment with baclofen blocked the PPI deficits induced by systemic PCP administration (interaction effect, $\mathrm{F}_{(1,28)}=5.597, p<0.05$ ). Post hoc analysis further supported this interpretation as PCP-treated animals had lower PPI than both controls $(p<0.01)$ and baclofen + PCP-treated animals $(p<0.05)$. In addition, the PPI of the baclofen + PCP group did not differ 

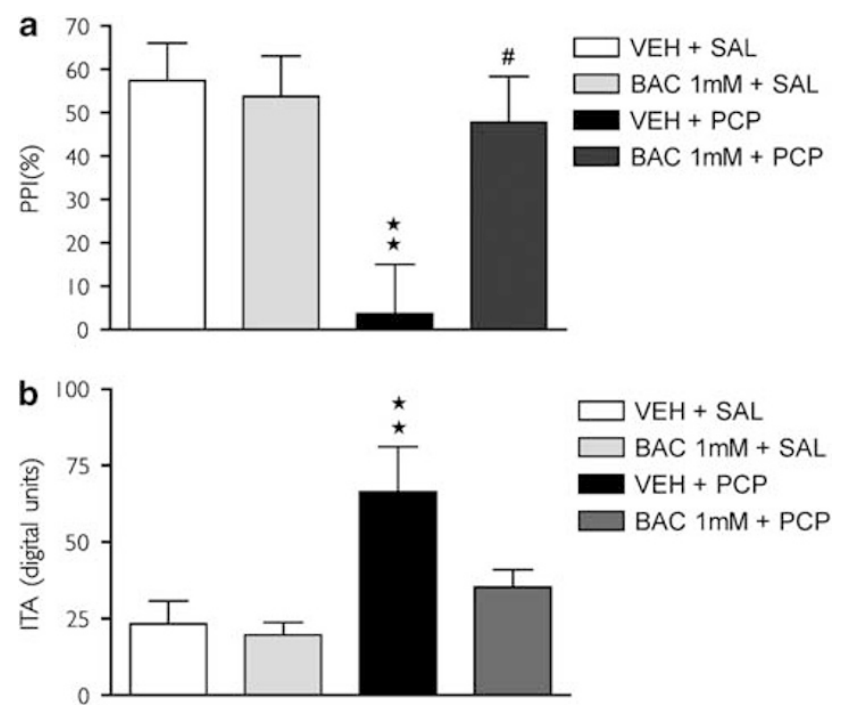

Figure 4 The effects of bilateral baclofen treatment (BAC; I mM) into the medial PFC followed by systemic PCP administration $(5 \mathrm{mg} / \mathrm{kg}$ ) on prepulse inhibition (PPI) and intertrial activity (ITA). Data are presented as mean PPI values collapsed over prepulse intensities \pm SEM for each treatment group. ( $\star^{\star} p<0.0$ I vs control group; ${ }^{\#} p<0.05$ vs PCP group; Bonferroni's test). (a) Prefrontal pretreatment with BAC blocks PCPinduced PPI disruption. (b) Prefrontal pretreatment with BAC partly blocks PCP-induced hyperactivity.

from the control group, suggesting a full blockade of the effects of PCP.

ASR was not affected by any treatment combination in experiment 3 (Table 1). ITA levels were significantly increased in PCP-treated animals (effect of treatment, $\left.\mathrm{F}_{(1,28)}=12.18, p<0.01\right)$ and animals locally pretreated with baclofen showed a decreased ITA (effect of pretreatment, $\mathrm{F}_{(1,28)}=4.234, p<0.05$; Figure $\left.4 \mathrm{~b}\right)$. No pretreatment $\times$ treatment interaction effect was present. Post hoc comparisons revealed a significantly increased ITA in the PCP group $(p<0.01)$ compared with controls, but did not show a difference between the baclofen + sal group and controls. Furthermore, PCP-treated animals did not differ from the baclofen + PCP group suggesting an inability of locally administered baclofen to block PCP-induced hyperactivity. However, the ITA of the baclofen + PCP group was not different from that of the control group, which in the absence of an interaction effect can be interpreted as a tendency to attenuate the effects of PCP.

Experiment 4: Pretreatment with a Low Dose of L-NAME does not Interfere with the Effects of PCP

L-NAME $(20 \mathrm{mg} / \mathrm{kg})$ administration did not produce a main effect on PPI whereas PCP significantly decreased PPI (effect of treatment, $\mathrm{F}_{(1,15)}=40.15, p<0.001$; Figure $2 \mathrm{c}$ ). No pretreatment $\times$ treatment interaction effect could be demonstrated and post hoc comparisons did not show any significant differences between the L-NAME + PCP group and PCP-treated animals. Both PCP-treated animals and the L-NAME + PCP group differed significantly from controls, confirming that this dose of L-NAME did not attenuate the effects of PCP on PPI.
ASR was not affected by any treatment combination in experiment 4 (Table 1). Statistical analysis showed a significant increase in ITA levels following PCP treatment (effect of treatment, $\mathrm{F}_{(1,15)}=37.94, p<0.001$; Figure $3 \mathrm{c}$ ) and a significant effect following pretreatment with L-NAME (effect of pretreatment, $\mathrm{F}_{(1,15)}=12.18, p<0.001$ ). Furthermore, a significant pretreatment $\times$ treatment interaction effect for ITA could be demonstrated (interaction effect, $\left.\mathrm{F}_{(1,15)}=6.220, p<0.05\right)$. Post hoc comparisons of ITA levels showed that PCP-treated animals had significantly higher ITA levels than controls $(p<0.05)$. L-NAME + PCP-treated animals had lower ITA levels than PCP-treated animals $(p<0.05)$, but also showed a significant increase in ITA compared to controls $(p<0.001)$ suggesting a partial attenuation of the PCP-induced hyperactivity.

\section{Experiment 5: Baclofen + L-NAME Combination Increases Basal PPI and Prevents the Effects of PCP}

Pretreatment with subthreshold doses of baclofen $(2.5 \mathrm{mg} /$ $\mathrm{kg})$ and L-NAME $(20 \mathrm{mg} / \mathrm{kg})$ significantly increased PPI (effect of pretreatment, $\mathrm{F}_{(1,15)}=21.58, p<0.001$; Figure 2d). As above, PCP-treatment decreased PPI levels (effect of treatment, $\left.\mathrm{F}_{(1,15)}=31.41, p<0.001\right)$ but no pretreatment $\times$ treatment interaction was present, suggesting additive effects of these two factors on PPI. Post hoc comparisons confirmed that the combined pretreatment increased PPI in an additive manner as the baclofen + L-NAME + sal group had significantly higher PPI than controls $(p<0.01)$. Additionally, the pretreatment appeared to prevent the effects of PCP, as the baclofen + L-NAME + PCP group had significantly higher PPI than PCP-treated animals $(p<0.05)$ but did not differ from controls.

ASR was not affected by any treatment combination in experiment 5 (Table 1). ITA was significantly increased after PCP treatment (effect of treatment, $\mathrm{F}_{(1,15)}=29.26, p<0.001$ ) and lowered after pretreatment with baclofen and L-NAME (effect of pretreatment, $\mathrm{F}_{(1,15)}=12.22, p<0.01$; Figure 3d). A significant pretreatment $\times$ treatment interaction (interaction effect, $\left.\mathrm{F}_{(1,15)}=16.66, p<0.001\right)$ suggested that the combined pretreatment blocked the effects of PCP on ITA. Post hoc analysis confirmed this as the significant increase in ITA levels following PCP $(p<0.001)$ could not be seen for the baclofen + L-NAME + PCP group whereas the latter group had significantly lower ITA than PCP-treated animals $(p<0.01)$.

\section{Experiment 6: Baclofen Decreases NO Levels in the mPFC}

Baclofen treatment significantly decreased the NO current over the sampling time (effect of treatment, $\mathrm{F}_{(3,18)}=4.233$, $p<0.05$; Figure 5). Furthermore, this effect was time dependent as evidenced by a treatment $\times$ time point $(30$, 60 , or $90 \mathrm{~min}$ ) interaction effect (interaction effect, $\left.\mathrm{F}_{(6,36)}=2.772, p<0.05\right)$. This warranted a detailed analysis for each time point. Analysis of the change in NO current at 30 min revealed no significant effect of baclofen treatment. At $60 \mathrm{~min}$ after injection, a main effect of baclofen could be detected (effect of treatment, $\mathrm{F}_{(3,18)}=3.264, p<0.05$ ) suggesting a decrease in NO current due to baclofen treatment. However, post hoc comparisons did not reveal 
a
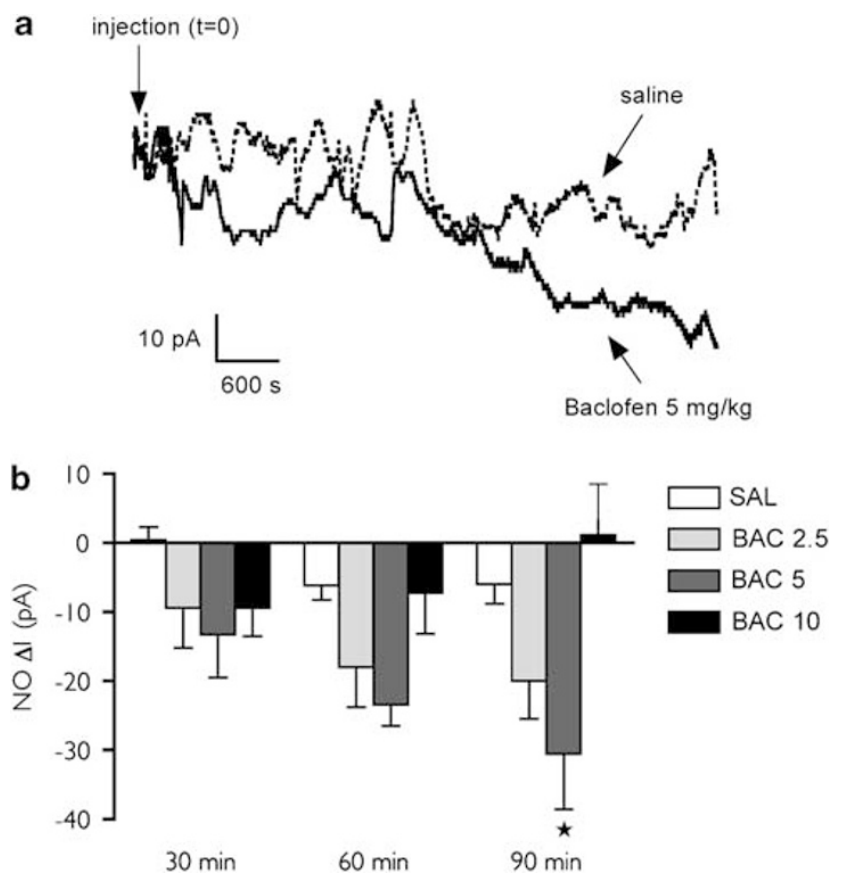

Figure 5 Prefrontal NO release is decreased following systemic baclofen administration. (a) A representative voltammogram showing the oxidation current in the medial prefrontal cortex after saline or baclofen $(5 \mathrm{mg} / \mathrm{kg}$, $t=0)$ administration. Data are expressed as current (pA) over time (seconds). (b) Change in prefrontal $\mathrm{NO}$ release 30,60, and $90 \mathrm{~min}$ after systemic baclofen administration. Data are presented as mean change in $\mathrm{NO}$ current compared to baseline \pm SEM for each treatment group ( ${ }^{\star} p<0.05$ vs control group, Bonferroni's test).

any significant difference between the control group and the different treatment groups, indicating that this decrease was relatively subtle. Finally, analysis of the change in NO current $90 \mathrm{~min}$ after injection revealed a significant decrease following baclofen treatment (effect of treatment, $\left.\mathrm{F}_{(3,18)}=5.118, p<0.01\right)$. Post hoc comparisons showed that baclofen $5 \mathrm{mg} / \mathrm{kg} \quad(p<0.05)$ significantly decreased NO levels, whereas this was not the case for $2.5 \mathrm{mg} / \mathrm{kg}$ or the $10 \mathrm{mg} / \mathrm{kg}$ dose. This indicates a dose-related effect of baclofen on NO levels in the medial PFC.

\section{DISCUSSION}

In this study, PCP-induced PPI deficits and hyperactivity were attenuated by systemic pretreatment with the $\mathrm{GABA}_{\mathrm{B}}$ agonist baclofen in a dose-related manner. Although systemic baclofen normalized PPI in an additive manner, prefrontal microinjections of baclofen completely blocked the PPI-disruption caused by PCP, without affecting this measure per se. Furthermore, the combination of baclofen and an NOS inhibitor was more effective in preventing the effects of PCP than any compound by itself. Additionally, in vivo measurements of NO levels showed that baclofen inhibited NO release in the PFC.

\section{Effects of Baclofen}

The finding that baclofen attenuates the disruptive effects of PCP on PPI, extends previous studies showing that systemic administration of this compound blocks the effects of the
NMDA receptor antagonist, dizocilpine (MK-801), in both rats (Bortolato et al, 2004) and mice (Arai et al, 2008). In addition, baclofen improves spontaneous PPI deficits in DBA/2J mice without affecting basal PPI in control mice (Bortolato et al, 2007). The above-mentioned studies have all demonstrated effects in a dose range similar to this study, although direct comparisons are somewhat complicated by interstudy differences in mice strain, rodent species, or baclofen enantiomer. One important difference is that baclofen $(5 \mathrm{mg} / \mathrm{kg})$ increased basal PPI in this study and thus attenuated the effects of PCP in an additive rather than interactive manner. Although such an increase is at variance with previous studies, the present findings point to a role of $\mathrm{GABA}_{\mathrm{B}}$ receptors in the regulation of preattentive information processing, possibly indicating that stimulation of these receptors may have an antipsychotic effect in patients. Early studies of the antipsychotic potential of baclofen showed beneficial effects in patients with schizophrenia (Frederiksen, 1975; Schopf and Hucker, 1977), although these findings were not replicated in later studies (Beckmann et al, 1977; Bigelow et al, 1977; Gulmann et al, 1976). In this study, the higher dose of baclofen $(5 \mathrm{mg} / \mathrm{kg})$ significantly lowered startle reactivity, possibly due to the muscle-relaxing properties of this compound. However, PPI does not appear to be correlated to either drug-induced or genotype-induced differences in ASR, suggesting that the decrease in ASR was not likely confounding the PPI measurements in experiment 2 (Klamer et al, 2005b; Paylor and Crawley, 1997).

At the lower dose $(2.5 \mathrm{mg} / \mathrm{kg})$ baclofen also blocked the hyperactivity caused by PCP as measured by ITA without affecting this measure in itself, in analogy to an earlier study in mice (Menon et al, 1980). A possible mechanism behind this may be that baclofen stabilizes dopamine neuron firing in the midbrain (Erhardt et al, 1998, 2002). In support of this, baclofen has proven effective against the disruption of PPI by metamphetamine (Arai et al, 2008), D-amphetamineinduced hypermotility and disruption of successive discrimination (Ahlenius et al, 1975; Phillis et al, 2001; Zhou et al, 2004). Although the hyperactivity caused by common psychotomimetics such as D-amphetamine, traditionally has been attributed to stimulation of the mesocorticolimbic dopamine system, this may not be true for NMDA receptor antagonists such as PCP where the effects on locomotion are temporally dissociated from changes in dopamine levels (Adams and Moghaddam, 1998). The present finding that prefrontal injections of baclofen partially block PCPinduced hyperactivity may be an additional sign that also changes in nondopaminergic cortical transmission should be considered as a part of the explanation.

\section{Regional Effects of Baclofen}

Local injection of baclofen in the medial PFC effectively blocked the PPI disruption caused by systemic PCP administration without affecting this measure per se. The apparent difference in the effects of systemic and prefrontal administration of baclofen on baseline PPI may result from the interference with GABA signaling at multiple brain regions following systemic injection. PPI is known to be modulated in a top-down manner by the PFC, and also by brain nuclei more proximal to the primary startle circuit 
such as the lateral globus pallidus (LGP) and the pedunculopontine nucleus (PPTg; Koch and Schnitzler, 1997; Kodsi and Swerdlow, 1997; Swerdlow et al, 2001). Interestingly, it was recently shown that PPTg-targeting GABAergic neurons in the LGP are activated at both prepulse and prepulse + pulse (PPI) conditions, and that transient inactivation of this region by lidocaine decreases PPI in mice. Furthermore, infusions of both $\mathrm{GABA}_{\mathrm{A}}$ and $\mathrm{GABA}_{\mathrm{B}}$ receptor antagonists into the PPTg decrease PPI, suggesting that the LGP regulates PPI by acting on GABA receptors in the PPTg (Diederich and Koch, 2005; Takahashi et al, 2007). Thus, it is possible that systemic (but not prefrontal) injections of baclofen used in this study, affects PPTg in the opposite direction, thereby causing an increase in basal PPI.

The present findings suggests that impairments in prefrontal $\mathrm{GABA}_{\mathrm{B}}$-mediated inhibition may be important for the effects of PCP on information processing and that restoration of inhibitory signaling through these receptors is sufficient to normalize PPI. It is now known that NMDA receptor antagonists stimulate cortical glutamate and dopamine release (Adams and Moghaddam, 1998; Moghaddam et al, 1997) and suppress inhibitory synaptic transmission (Zhang et al, 2008). Interestingly, perfusion of baclofen into the PFC has been demonstrated to decrease both basal dopamine release and NO release in this region (Ishizuka et al, 2000; Santiago et al, 1993) and also to block the behavioral arousal and hyperlocomotion caused by the NMDA receptor antagonist AP-5 (Feenstra et al, 2002). Prefrontal injections of baclofen also inhibit stimulated glutamate release in the ventral tegmental area, which receives corticofugal projections from the PFC and consequently reflects the degree of prefrontal excitation (Harte and O'Connor, 2005). Thus, the present effects of baclofen may be explained as a restoration of inhibitory function followed by stabilization of aberrant glutamate release and/ or by an interaction with the dopamine and NO systems in the PFC. Notably, GABA $\mathrm{B}$ receptor expression appears to be reduced both in the $\mathrm{PFC}$, entorhinal cortex, and hippocampus of subjects with schizophrenia, indicating that these receptors may have an important role in the pathophysiology of the disease (Ishikawa et al, 2005; Mizukami et al, 2000, 2002).

\section{$\mathrm{GABA}_{\mathrm{B}}$ and Nitric Oxide}

The combination of subthreshold doses of baclofen and L-NAME was more effective in preventing the effects of PCP than any compound by itself. However, the increasing effect of pretreatment on PPI, in combination with the absence of a pretreatment $\times$ treatment interaction, suggests that this effect mainly is of an additive nature. An important observation is that neither baclofen nor L-NAME (at subthreshold doses) increased basal PPI levels, whereas this effect was evident for their combination. This finding opens up the possibility of a connection between $\mathrm{GABA}_{B}$ receptors and NO release in the regulation of PPI. A similar relationship between these two signaling systems has previously been described in the hippocampus where basal cGMP efflux is increased by local administration of $\mathrm{GABA}_{\mathrm{B}}$ antagonists and decreased by baclofen (Fedele et al, 1997). Future studies using local pretreatment with $\mathrm{GABA}_{\mathrm{B}}$ antagonists in the PFC, may clarify whether the observed normalizing effect of baclofen/L-NAME on disrupted PPI is dependent on prefrontal $\mathrm{GABA}_{\mathrm{B}}$ receptor signaling.

In this study, systemic baclofen administration decreased NO levels over time in the rat medial PFC, indicating that cortical NO release may be under the influence of upstream $\mathrm{GABA}_{\mathrm{B}}$ receptor signaling. It has been shown that release of both glutamate and the effector of NO signaling, cGMP, are decreased by baclofen but increased by $\mathrm{GABA}_{\mathrm{B}}$ antagonists (Fedele et al, 1997; Harte and O'Connor, 2005; Waldmeier et al, 2008). Consequently, antagonists of the $\mathrm{GABA}_{\mathrm{B}}$ receptor may elevate NO levels, possibly through a disinhibitory activation of glutamate receptors. A similar disinhibition pattern could theoretically arise from blocking NMDA receptors on interneurons with $\mathrm{PCP}$, where an increase in glutamate, instead, may act on $\mathrm{Ca}^{2+}$-permeable AMPA receptors to regulate NO release. Interestingly most neurons that express this subtype of AMPA receptor and/or produce NO are GABAergic interneurons (Gabbott and Bacon, 1995; Jonas et al, 1994; Szabadits et al, 2007; Yan et al, 1996; Yin et al, 1994).

The decrease in NO levels was most pronounced at a time point (60-90 min) coinciding with the time for PPI measurements following baclofen injection. Tentatively, the temporal association between the effects of baclofen on PPI and NO release gives further support to the hypothesis that NO signaling in the medial PFC may be partly responsible for the effects of baclofen on PPI. Although the medium dose of baclofen $(5 \mathrm{mg} / \mathrm{kg})$ potently decreased NO levels, this effect was completely absent for the highest dose $(10 \mathrm{mg} / \mathrm{kg})$. This 'inverted U'-like shape of the dose response curve remains to be explained, but may possibly reflect a more widespread engagement of $\mathrm{GABA}_{B}$ receptors in the brain, paralleled with the visibly decreased basal activity at this dose, which is likely to be caused by the muscle-relaxing and sedative effects of baclofen (Nevins et al, 1993). Additionally, $\mathrm{GABA}_{\mathrm{B}}$ receptors are coupled to $\mathrm{G}$ proteins, $\mathrm{Ca}^{2+}$ channels, $\mathrm{K}^{+}$channels, and adenylyl cyclase, and are situated both presynaptically as auto- or heteroreceptors and at postsynaptic neurons. Thus, these receptors are capable of modulating release of various neurotransmitters as well as hyperpolarizing the postsynaptic membrane potential (for review see Bettler et al, 2004; Couve et al, 2000) and this complexity should call for caution when interpreting the above-mentioned results.

\section{Concluding Remarks}

This study demonstrates that signaling through $\mathrm{GABA}_{B}$ receptors mediates certain effects of $\mathrm{PCP}$ on information processing and that the PFC is strongly implicated in these effects. Furthermore, an interaction between $\mathrm{GABA}_{B}$ and NO signaling was detected as evidenced by converging effects of these pathways on PPI and on prefrontal NO release in vivo. Baclofen had an effect on PPI per se following systemic, but not prefrontal injections, tentatively indicating that $\mathrm{GABA}_{\mathrm{B}}$ receptors in the PFC are involved in the effects of PCP but not in the modulation of baseline PPI. Taken together, the present findings support recent hypotheses on compromised inhibition following administration of NMDA receptor antagonists leading to a disinhibition of the PFC (Tanaka, 2008; Zhang et al, 
2008). Interestingly, activation of the hippocampus and PFC in patients with schizophrenia has been demonstrated in some, but not all, studies of cerebral blood flow (Catafau et al, 1994; Friston et al, 1992; Ingvar and Franzen, 1974; Malaspina et al, 2004; Taylor et al, 2007). The recent finding that the mGlu2/3 receptor agonist LY2140023 significantly improves positive and negative symptoms in schizophrenia (Patil et al, 2007), also points in the direction of disinhibition, as the most likely effect of this compound is to reduce glutamate signaling in the brain. This study proposes a role for $G_{A B A}$ receptor signaling in the effects of PCP, possibly with altered NO levels as a downstream mediator. These results expand the recent finding that prefrontal NO/sGC signaling is important for the effects of PCP (Fejgin et al, 2008) and provide behavioral and biochemical support for $\mathrm{NO}$ as an effector of a disinhibited PFC. Future studies of the glutamate/ $\mathrm{GABA}_{\mathrm{B}} / \mathrm{NO}$ signaling pathway may bring greater insight into the mechanisms underlying cortical disinhibition in relation to disrupted information processing, and thus their putative importance for cognitive deficits in schizophrenia.

\section{ACKNOWLEDGEMENTS}

This study was supported by grants from Adlerbertska Forskningsstiftelsen, AstraZeneca, Sweden, the Swedish Medical Research Council (4247), Wilhelm och Martina Lundgrens Vetenskapsfond, Hjärnfonden, Jubileumsfonden, Konrad och Helfrid Johanssons fond, The Lundbeck Foundation, the Royal Society of Chemistry (Analytical Division), Schizofrenisällskapet, Stiftelsen Goljes Minne, Stiftelsen Tornspiran, Svenska Läkarsällskapet (the Swedish Society of Medicine), Svenska Sällskapet för Medicinsk Forskning (the Swedish Society for Medical Research), Åhlen-stiftelsen, and Åke Wibergs Stiftelse. We gratefully acknowledge the technical assistance of Farhad Rahavard, Kristina Durrance, and Kenn Johannessen.

\section{DISCLOSURE/CONFLICTS OF INTEREST}

The authors hereby declare that no financial support or compensation has been received from any individual or corporate entity over the past 3 years for research or professional service, and there are no personal financial holdings that could be perceived as constituting a potential conflict of interest.

\section{REFERENCES}

Adams B, Moghaddam B (1998). Corticolimbic dopamine neurotransmission is temporally dissociated from the cognitive and locomotor effects of phencyclidine. J Neurosci 18: 5545-5554.

Ahlenius S, Carlsson A, Engel J (1975). Antagonism by baclophen of the d-amphetamine-induced disruption of a successive discrimination in the rat. J Neural Transm 36: 327-333.

Akbarian S, Kim JJ, Potkin SG, Hagman JO, Tafazzoli A, Bunney Jr WE et al (1995). Gene expression for glutamic acid decarboxylase is reduced without loss of neurons in prefrontal cortex of schizophrenics. Arch Gen Psychiatry 52: 258-266.

Arai S, Takuma K, Mizoguchi H, Ibi D, Nagai T, Takahashi K et al (2008). Involvement of pallidotegmental neurons in methamphetamine- and MK-801-induced impairment of prepulse inhibition of the acoustic startle reflex in mice: reversal by GABA(B) receptor agonist baclofen. Neuropsychopharmacology 33: 3164-3175.

Beckmann H, Frische M, Ruther E, Zimmer R (1977). Baclofen (para-chlorphenyl-GABA) in schizophrenia. Pharmakopsychiatr Neuropsychopharmakol 10: 26-31.

Behrens MM, Ali SS, Dao DN, Lucero J, Shekhtman G, Quick KL et al (2007). Ketamine-induced loss of phenotype of fast-spiking interneurons is mediated by NADPH-oxidase. Science 318: 1645-1647.

Benes FM (1999). Evidence for altered trisynaptic circuitry in schizophrenic hippocampus. Biol Psychiatry 46: 589-599.

Benes FM, McSparren J, Bird ED, SanGiovanni JP, Vincent SL (1991). Deficits in small interneurons in prefrontal and cingulate cortices of schizophrenic and schizoaffective patients. Arch Gen Psychiatry 48: 996-1001.

Benes FM, Vincent SL, Todtenkopf M (2001). The density of pyramidal and nonpyramidal neurons in anterior cingulate cortex of schizophrenic and bipolar subjects. Biol Psychiatry 50: 395-406.

Bettler B, Kaupmann K, Mosbacher J, Gassmann M (2004). Molecular structure and physiological functions of GABA(B) receptors. Physiol Rev 84: 835-867.

Bigelow LB, Nasrallah H, Carman J, Gillin JC, Wyatt RJ (1977). Baclofen treatment in chronic schizophrenia: a clinical trial. Am J Psychiatry 134: 318-320.

Bortolato M, Frau R, Aru GN, Orru M, Gessa GL (2004). Baclofen reverses the reduction in prepulse inhibition of the acoustic startle response induced by dizocilpine, but not by apomorphine. Psychopharmacology (Berl) 171: 322-330.

Bortolato M, Frau R, Orru M, Piras AP, Fa M, Tuveri A et al (2007). Activation of $\mathrm{GABA}(\mathrm{B})$ receptors reverses spontaneous gating deficits in juvenile DBA/2J mice. Psychopharmacology (Berl) 194: 361-369.

Breier A, Malhotra AK, Pinals DA, Weisenfeld NI, Pickar D (1997). Association of ketamine-induced psychosis with focal activation of the prefrontal cortex in healthy volunteers. Am J Psychiatry 154: 805-811.

Brown FO, Finnerty NJ, Bolger FB, Millar J, Lowry JP (2005). Calibration of NO sensors for in-vivo voltammetry: laboratory synthesis of NO and the use of UV-visible spectroscopy for determining stock concentrations. Anal Bioanal Chem 381: 964-971.

Brown FO, Lowry JP (2003). Microelectrochemical sensors for in vivo brain analysis: an investigation of procedures for modifying Pt electrodes using Nafion. Analyst 128: 700-705.

Catafau AM, Parellada E, Lomena FJ, Bernardo M, Pavia J, Ros D et al (1994). Prefrontal and temporal blood flow in schizophrenia: resting and activation technetium-99m-HMPAO SPECT patterns in young neuroleptic-naive patients with acute disease. J Nucl Med 35: 935-941.

Couve A, Moss SJ, Pangalos MN (2000). GABAB receptors: a new paradigm in G protein signaling. Mol Cell Neurosci 16: 296-312.

Cross AJ, Crow TJ, Owen F (1979). Gamma-aminobutyric acid in the brain in schizophrenia. Lancet 1: 560-561.

Diederich K, Koch M (2005). Role of the pedunculopontine tegmental nucleus in sensorimotor gating and reward-related behavior in rats. Psychopharmacology (Berl) 179: 402-408.

Erhardt S, Andersson B, Nissbrandt H, Engberg G (1998). Inhibition of firing rate and changes in the firing pattern of nigral dopamine neurons by gamma-hydroxybutyric acid (GHBA) are specifically induced by activation of GABA(B) receptors. Naunyn Schmiedebergs Arch Pharmacol 357: 611-619.

Erhardt S, Mathe JM, Chergui K, Engberg G, Svensson TH (2002). $\mathrm{GABA}(\mathrm{B})$ receptor-mediated modulation of the firing pattern of ventral tegmental area dopamine neurons in vivo. Naunyn Schmiedebergs Arch Pharmacol 365: 173-180. 
Fedele E, Varnier G, Raiteri M (1997). In vivo microdialysis study of $\mathrm{GABA}(\mathrm{A})$ and $\mathrm{GABA}(\mathrm{B})$ receptors modulating the glutamate receptor/NO/cyclic GMP pathway in the rat hippocampus. Neuropharmacology 36: 1405-1415.

Feenstra MG, Botterblom MH, van Uum JF (2002). Behavioral arousal and increased dopamine efflux after blockade of NMDAreceptors in the prefrontal cortex are dependent on activation of glutamatergic neurotransmission. Neuropharmacology 42: 752-763.

Fejgin K, Palsson E, Wass C, Svensson L, Klamer D (2008). Nitric oxide signaling in the medial prefrontal cortex is involved in the biochemical and behavioral effects of phencyclidine. Neuropsychopharmacology 33: 1874-1883.

Fejgin K, Safonov S, Palsson E, Wass C, Engel JA, Svensson L et al (2007). The atypical antipsychotic, aripiprazole, blocks phencyclidine-induced disruption of prepulse inhibition in mice. Psychopharmacology (Berl) 191: 377-385.

Finnerty N (2008). Electrochemical Sensors: In-Vitro and In-Vivo Analysis of Brain Nitric Oxide and Regional Cerebral Blood Flow. National University of Ireland Maynooth: Maynooth.

Franklin KBJ, Paxinos G (1996). The Mouse Brain in Stereotaxic Coordinates. Academic Press: New York.

Frederiksen PK (1975). Letter: Baclofen in the treatment of schizophrenia. Lancet 1: 702.

Freedman R, Adler LE, Gerhardt GA, Waldo M, Baker N, Rose GM et al (1987). Neurobiological studies of sensory gating in schizophrenia. Schizophr Bull 13: 669-678.

Friston KJ, Liddle PF, Frith CD, Hirsch SR, Frackowiak RS (1992). The left medial temporal region and schizophrenia. A PET study. Brain 115(Part 2): 367-382.

Gabbott PL, Bacon SJ (1995). Co-localisation of NADPH diaphorase activity and GABA immunoreactivity in local circuit neurones in the medial prefrontal cortex (mPFC) of the rat. Brain Res 699: 321-328.

Gozzi A, Large CH, Schwarz A, Bertani S, Crestan V, Bifone A (2008). Differential effects of antipsychotic and glutamatergic agents on the phMRI response to phencyclidine. Neuropsychopharmacology 33: 1690-1703.

Grunze HC, Rainnie DG, Hasselmo ME, Barkai E, Hearn EF, McCarley RW et al (1996). NMDA-dependent modulation of CA1 local circuit inhibition. J Neurosci 16: 2034-2043.

Gulmann NC, Bahr B, Andersen B, Eliassen HM (1976). A doubleblind trial of baclofen against placebo in the treatment of schizophrenia. Acta Psychiatr Scand 54: 287-293.

Harte M, O'Connor WT (2005). Evidence for a selective prefrontal cortical $\mathrm{GABA}(\mathrm{B})$ receptor-mediated inhibition of glutamate release in the ventral tegmental area: a dual probe microdialysis study in the awake rat. Neuroscience 130: 215-222.

Hashimoto T, Bazmi HH, Mirnics K, Wu Q, Sampson AR, Lewis DA (2008). Conserved regional patterns of GABA-related transcript expression in the neocortex of subjects with schizophrenia. Am J Psychiatry 165: 479-489.

Hashimoto T, Volk DW, Eggan SM, Mirnics K, Pierri JN, Sun Z et al (2003). Gene expression deficits in a subclass of GABA neurons in the prefrontal cortex of subjects with schizophrenia. J Neurosci 23: 6315-6326.

Homayoun H, Moghaddam B (2007). NMDA receptor hypofunction produces opposite effects on prefrontal cortex interneurons and pyramidal neurons. J Neurosci 27: 11496-11500.

Ingvar DH, Franzen G (1974). Distribution of cerebral activity in chronic schizophrenia. Lancet 2: 1484-1486.

Ishikawa M, Mizukami K, Iwakiri M, Asada T (2005). Immunohistochemical and immunoblot analysis of gamma-aminobutyric acid B receptor in the prefrontal cortex of subjects with schizophrenia and bipolar disorder. Neurosci Lett 383: 272-277.

Ishizuka Y, Ishida Y, Jin QH, Mitsuyama Y, Kannan H (2000). $\mathrm{GABA}(\mathrm{A})$ and $\mathrm{GABA}(\mathrm{B})$ receptors modulating basal and footshock-induced nitric oxide releases in rat prefrontal cortex. Brain Res 872: 266-270.
Jackson ME, Homayoun H, Moghaddam B (2004). NMDA receptor hypofunction produces concomitant firing rate potentiation and burst activity reduction in the prefrontal cortex. Proc Natl Acad Sci USA 101: 8467-8472.

Javitt DC, Zukin SR (1991). Recent advances in the phencyclidine model of schizophrenia. Am J Psychiatry 148: 1301-1308.

Jentsch JD, Tran A, Le D, Youngren KD, Roth RH (1997). Subchronic phencyclidine administration reduces mesoprefrontal dopamine utilization and impairs prefrontal corticaldependent cognition in the rat. Neuropsychopharmacology 17: 92-99.

Johansson C, Jackson DM, Svensson L (1997). Nitric oxide synthase inhibition blocks phencyclidine-induced behavioural effects on prepulse inhibition and locomotor activity in the rat. Psychopharmacology (Berl) 131: 167-173.

Jonas P, Racca C, Sakmann B, Seeburg PH, Monyer H (1994). Differences in $\mathrm{Ca} 2+$ permeability of AMPA-type glutamate receptor channels in neocortical neurons caused by differential GluR-B subunit expression. Neuron 12: 1281-1289.

Jones RS, Buhl EH (1993). Basket-like interneurones in layer II of the entorhinal cortex exhibit a powerful NMDA-mediated synaptic excitation. Neurosci Lett 149: 35-39.

Klamer D, Engel JA, Svensson L (2001). The nitric oxide synthase inhibitor, L-NAME, blocks phencyclidine-induced disruption of prepulse inhibition in mice. Psychopharmacology (Berl) 156: 182-186.

Klamer D, Engel JA, Svensson L (2004). The neuronal selective nitric oxide synthase inhibitor, Nomega-propyl-L-arginine, blocks the effects of phencyclidine on prepulse inhibition and locomotor activity in mice. Eur J Pharmacol 503: 103-107.

Klamer D, Engel JA, Svensson L (2005a). Effects of phencyclidine on acoustic startle and prepulse inhibition in neuronal nitric oxide synthase deficient mice. Eur Neuropsychopharmacol 15: 587-590.

Klamer D, Palsson E, Fejgin K, Zhang J, Engel JA, Svensson L (2005b). Activation of a nitric-oxide-sensitive cAMP pathway with phencyclidine: elevated hippocampal cAMP levels are temporally associated with deficits in prepulse inhibition. Psychopharmacology (Berl) 179: 479-488.

Koch M, Schnitzler HU (1997). The acoustic startle response in rats - circuits mediating evocation, inhibition and potentiation. Behav Brain Res 89: 35-49.

Kodsi MH, Swerdlow NR (1997). Regulation of prepulse inhibition by ventral pallidal projections. Brain Res Bull 43: 219-228.

Lahti AC, Holcomb HH, Medoff DR, Tamminga CA (1995). Ketamine activates psychosis and alters limbic blood flow in schizophrenia. Neuroreport 6: 869-872.

Lewis DA, Moghaddam B (2006). Cognitive dysfunction in schizophrenia: convergence of gamma-aminobutyric acid and glutamate alterations. Arch Neurol 63: 1372-1376.

Linn GS, Negi SS, Gerum SV, Javitt DC (2003). Reversal of phencyclidine-induced prepulse inhibition deficits by clozapine in monkeys. Psychopharmacology (Berl) 169: 234-239.

Lisman JE, Coyle JT, Green RW, Javitt DC, Benes FM, Heckers S et al (2008). Circuit-based framework for understanding neurotransmitter and risk gene interactions in schizophrenia. Trends Neurosci 31: 234-242.

Lowry JP, Boutelle MG, Fillenz M (1997). Measurement of brain tissue oxygen at a carbon past electrode can serve as an index of increases in regional cerebral blood flow. J Neurosci Methods 71: 177-182.

Luby ED, Cohen BD, Rosenbaum G, Gottlieb LS, Kelly R (1959). Study of a new schizophrenomimetic drug-sernyl. Arch Neurol Psychiatry 81: 363-369.

Malaspina D, Harkavy-Friedman J, Corcoran C, Mujica-Parodi L, Printz D, Gorman JM et al (2004). Resting neural activity distinguishes subgroups of schizophrenia patients. Biol Psychiatry 56: 931-937. 
Mansbach RS, Geyer MA (1989). Effects of phencyclidine and phencyclidine biologs on sensorimotor gating in the rat. Neuropsychopharmacology 2: 299-308.

Menon MK, Clark WG, Vivonia C (1980). Interaction between phencyclidine (PCP) and GABA-ergic drugs: clinical implications. Pharmacol Biochem Behav 12: 113-117.

Mizukami K, Ishikawa M, Hidaka S, Iwakiri M, Sasaki M, Iritani S (2002). Immunohistochemical localization of GABAB receptor in the entorhinal cortex and inferior temporal cortex of schizophrenic brain. Prog Neuropsychopharmacol Biol Psychiatry 26: 393-396.

Mizukami K, Sasaki M, Ishikawa M, Iwakiri M, Hidaka S, Shiraishi $\mathrm{H}$ et al (2000). Immunohistochemical localization of gammaaminobutyric acid(B) receptor in the hippocampus of subjects with schizophrenia. Neurosci Lett 283: 101-104.

Moghaddam B, Adams B, Verma A, Daly D (1997). Activation of glutamatergic neurotransmission by ketamine: a novel step in the pathway from NMDA receptor blockade to dopaminergic and cognitive disruptions associated with the prefrontal cortex. J Neurosci 17: 2921-2927.

Nevins ME, Nash SA, Beardsley PM (1993). Quantitative grip strength assessment as a means of evaluating muscle relaxation in mice. Psychopharmacology (Berl) 110: 92-96.

Palsson E, Fejgin K, Wass C, Engel JA, Svensson L, Klamer D (2007). The amino acid L-lysine blocks the disruptive effect of phencyclidine on prepulse inhibition in mice. Psychopharmacology (Berl) 192: 9-15.

Patil ST, Zhang L, Martenyi F, Lowe SL, Jackson KA, Andreev BV et al (2007). Activation of mGlu2/3 receptors as a new approach to treat schizophrenia: a randomized Phase 2 clinical trial. Nat Med 13: 1102-1107.

Paxinos G, Watson C (2005). The Rat Brain in Stereotaxic Coordinates. Academic Press: New York.

Paylor R, Crawley JN (1997). Inbred strain differences in prepulse inhibition of the mouse startle response. Psychopharmacology (Berl) 132: 169-180.

Perry TL, Kish SJ, Buchanan J, Hansen S (1979). Gammaaminobutyric-acid deficiency in brain of schizophrenic patients. Lancet 1: 237-239.

Phillis BD, Ong J, White JM, Bonnielle C (2001). Modification of damphetamine-induced responses by baclofen in rats. Psychopharmacology (Berl) 153: 277-284.

Santiago M, Machado A, Cano J (1993). In vivo release of dopamine from rat striatum, substantia nigra and prefrontal cortex: differential modulation by baclofen. Br J Pharmacol 109: 814-818.

Schopf J, Hucker H (1977). Baclofen in the treatment of schizophrenia: a pilot study. Pharmakopsychiatr Neuropsychopharmakol 10: 89-91.

Swerdlow NR, Geyer MA, Braff DL (2001). Neural circuit regulation of prepulse inhibition of startle in the rat: current knowledge and future challenges. Psychopharmacology (Berl) 156: 194-215.
Szabadits E, Cserep C, Ludanyi A, Katona I, Gracia-Llanes J, Freund TF et al (2007). Hippocampal GABAergic synapses possess the molecular machinery for retrograde nitric oxide signaling. J Neurosci 27: 8101-8111.

Takahashi K, Nagai T, Kamei H, Maeda K, Matsuya T, Arai S et al (2007). Neural circuits containing pallidotegmental GABAergic neurons are involved in the prepulse inhibition of the startle reflex in mice. Biol Psychiatry 62: 148-157.

Tanaka S (2008). Dysfunctional GABAergic inhibition in the prefrontal cortex leading to 'psychotic' hyperactivation. $B M C$ Neurosci 9: 41.

Taylor SF, Welsh RC, Chen AC, Velander AJ, Liberzon I (2007). Medial frontal hyperactivity in reality distortion. Biol Psychiatry 61: 1171-1178.

Waldmeier PC, Kaupmann K, Urwyler S (2008). Roles of GABA(B) receptor subtypes in presynaptic auto- and heteroreceptor function regulating GABA and glutamate release. J Neural Transm 115: 1401-1411.

Wass C, Archer T, Palsson E, Fejgin K, Alexandersson A, Klamer D et al (2006a). Phencyclidine affects memory in a nitric oxidedependent manner: working and reference memory. Behav Brain Res 174: 49-55.

Wass C, Archer T, Palsson E, Fejgin K, Klamer D, Engel JA et al (2006b). Effects of phencyclidine on spatial learning and memory: Nitric oxide-dependent mechanisms. Behav Brain Res 171: 147-153.

Wass C, Svensson L, Fejgin K, Palsson E, Archer T, Engel JA et al (2008). Nitric oxide synthase inhibition attenuates phencyclidine-induced disruption of cognitive flexibility. Pharmacol Biochem Behav 89: 352-359.

Woo TU, Walsh JP, Benes FM (2004). Density of glutamic acid decarboxylase 67 messenger RNA-containing neurons that express the N-methyl-D-aspartate receptor subunit NR2A in the anterior cingulate cortex in schizophrenia and bipolar disorder. Arch Gen Psychiatry 61: 649-657.

Yan XX, Jen LS, Garey LJ (1996). NADPH-diaphorasepositive neurons in primate cerebral cortex colocalize with GABA and calcium-binding proteins. Cereb Cortex 6: 524-529.

Yesavage JA, Freman AM (1978). Acute phencyclidine (PCP) intoxication: psychopathology and prognosis. J Clin Psychiatry 39: 664-666.

Yin H, Turetsky D, Choi DW, Weiss JH (1994). Cortical neurones with $\mathrm{Ca} 2+$ permeable AMPA/kainate channels display distinct receptor immunoreactivity and are GABAergic. Neurobiol Dis 1: 43-49.

Zhang Y, Behrens MM, Lisman JE (2008). Prolonged exposure to NMDAR antagonist suppresses inhibitory synaptic transmission in prefrontal cortex. J Neurophysiol 100: 959-965.

Zhou W, Mailloux AW, Jung BJ, Edmunds Jr HS, McGinty JF (2004). GABAB receptor stimulation decreases amphetamineinduced behavior and neuropeptide gene expression in the striatum. Brain Res 1004: 18-28. 